\title{
KEBIJAKAN-KEBIJAKAN KEPALA SEKOLAH DALAM PENYELENGGARAAN PENDIDIKAN INKLUSIF DI SEKOLAH X KOTA JAMBI
}

\author{
Johandri Taufan, Fachri Mazhud \\ Dosen Universitas Negeri Padang \\ Email: joe.handry@rocketmail.com, \\ fachrimazhud@rocketmail.com
}

\begin{abstract}
ABSTRAK
Tujuan dari penelitian ini adalah untuk menemukan dan memperoleh gambaran tentang kebijakan-kebijakan seperti apa yang dilakukan kepala sekolah sebagai usaha-usaha kepala sekolah dalam penyelenggaraan pendidikan inklusif di Sekolah X Kota Jambi. Fokus penelitian ini meliputi beberapa aspek yaitu, peran kepala sekolah dalam pengambilan kebijakan penyelenggaraan pendidikan inklusif, pendukung dan penghambat kepala sekolah dalam pengambilan kebijakan penyelenggaraan pendidikan inklusif dan desain kebijakan kepala sekolah dalam penyelenggaraan pendidikan inklusif. Dari hasil penelitian dan pembahasan kemudian disimpulkan bahwa kebijakan-kebijakan kepala sekolah dalam penyelenggaraan pendidikan inklusif di Sekolah X Kota Jambi berjalan dengan baik. Masyarakat sekolah sangat mendukung kebijakan-kebijakan yang di buat oleh kepala sekolah sebagai sebuah usaha-usaha kepala sekolah dalam penyelenggaraan pendidikan inklusif di Sekolah X Kota Jambi. Dari proses hasil penelitian dan pembahasan ini, disusunlah sebuah desain kebijakan yang merupakan hasil desain peneliti terkait pengambilan kebijakan yang dilakukan oleh kepala sekolah. Desain kebijakan kepala sekolah dalam penyelenggaraan pendidikan inklusif di Sekolah X Kota Jambi memberikan kejelasan mengenai hal-hal yang akan dilakukan dalam upaya mencapai tujuan kebijakan yang diharapkan.
\end{abstract}

Kata kunci: sekolah inklusif, kebijakan-kebijakan, kepala sekolah

\section{ABSTRACT}

The target of this research is to find and get picture about policys like what conducted of headmaster as efforts headmaster in implementation of inklusif education in school X of Jambi city. This research focus is policys of headmaster covering some aspect that is the role of headmaster in intake of policy of management of education of inklusif, supporter and resistor of headmaster interpretation policy management of inklusif education and policy desain of headmaster in implementation of inklusif education. From result of research and study then concluded is policy of headmaster in implementation of inklusif education in the school X of Jambi city is walking better. The school society very supporting about policy which made by headmaster as effort in implementation of inklusif education in the school X of Jambi city. From the process result of research and solution is complied by a policy desain representing resut of related research desain of in take policy conducted by headmaster. Desain policy of headmaster in implementation inklusif of education in the school X of Jambi city giving clarity concerning things to be continued in the effort reaching the target of expected policy

Keywords: school inclusion, policys, headmaster

\section{PENDAHULUAN}

Pendidikan inklusif sebagai sebuah pendekatan untuk memenuhi kebutuhan pendidikan dan belajar dari semua anak, remaja dan orang dewasa yang difokuskan secara spesifik kepada mereka yang disabilitas, terpinggirkan dan terabaikan. Prinsip pendidikan inklusif diadopsi dari. Konfrensi Salamanca tentang Pendidikan Kebutuhan Khusus (UNESCO, 1994) dan di ulang kembali pada Forum Pendidikan
Dunia di Dakar tahun 2000. Pendidikan inklusif mempunyai arti bahwa: sekolah harus mengakomodasi semua anak tanpa memperdulikan keadaan fisik, intelektual, social, emosi, bahasa, atau kondisi-kondisi lain, termasuk anak-anak penyandang cacat, anak-anak berbakat (gifted children), pekerja anak dan anak jalanan, anak di daerah terpencil, anak-anak dari kelompok etnik dan bahasa minoritas serta anak-anak yang tidak beruntung dan terpinggirkan dari kelompok 
masyarakat (Salamanca Statement, 1994).

Pendidikan inklusif merupakan sebuah pendekatan yang melihat bagaimana mengubah sistem pendidikan agar dapat merespon dan menerima keberagaman peserta didik, dengan tujuan guru dan siswa merasa nyaman dalam keberagaman, dan melihat keberagaman sebagai suatu tantangan dan pengayaan dalam lingkungan belajar, karena keberagaman bukanlah suatu masalah yang harus ditakuti.

Keberadaan sekolah sebagai lembaga formal penyelenggaraan pendidikan memainkan peran strategis dalam keberhasilan sistem pendidikan nasional. Kepala sekolah sebagai manajer dan pemimpin adalah bertanggung jawab dalam menerjemahkan dan melaksanakan kebijakan pendidikan nasional yang ditetapkan pemerintah (Syafaruddin, 2008). Berawal dari UUD 1945, Undangundang, peraturan pemerintah, keputusan presiden, instruksi presiden, keputusan menteri, sampai kepada peraturan daerah provinsi, peraturan daerah kabupaten dan kota, kemudian diterjemahkan dan dilaksanakan oleh kepala sekolah untuk menyentuh langsung keperluan stakeholders pendidikan, khususnya anak didik. Jadi, setiap kebijakan harus selalu berhubungan dengan kesejahteraan dan pencerdasan masyarakat

Perlu dicermati oleh kepala sekolah dalam membuat kebijakan baru adalah menciptakan keadaan baru. Suatu kebijakan baru merupakan penciptaan keadaan baru dari rutinitas yang memungkinkan mendapat penolakan dari personel sekolah. Karena itu, perlu melibatkan personel sekolah dalam membuat dan mengimplementasikan kebijakan baru sekolah supaya ada proses pembelajaran, dan komitmen dalam keberhasilan kebijakan meningkatkan mutu sekolah.

Tahun 2004 pendidikan inklusif di Provinsi Jambi baru mulai dirintis dengan ditunjuknya tiga Sekolah Dasar Negeri, yaitu satu di Kota Jambi, satu di Kabupaten Muara Jambi dan satu lagi di Kabupaten Bungo. Di tiga sekolah ini pendidikan inklusi berjalan dengan berbagai hambatan dan kesulitan yang perlu mendapatkan perhatian dan bantuan dari berbagai pihak. Seiring dengan meningkatnya kesadaran (rasa penerimaan, keterbukaan, keingintahuan) khususnya dari kepala sekolah dan sebagian guru reguler kini sekolah inklusif makin berkembang.

Pendidikan inklusi di Jambi bukan hanya berlangsung di beberapa Sekolah Dasar tetapi juga di beberapa SMP dan SMA/ SMK. Daftar siswa inklusi Propinsi Jambi hingga Maret 2012 terdapat 72 orang siswa inklusi yang terdiri dari siswa SD, SMP dan SMA/SMK (Sumber dari Ketua Forum Komunikasi Inklusi Propinsi Jambi, Maret 2012)

Fenomena yang peneliti temukan dilapangan, tepatnya di salah satu Sekolah X di Kota Jambi, peneliti menemukan bahwasanya Sekolah $X$ telah menyelenggarakan pendidikan inklusif sejak tahun 2004 lalu. Penyelenggaraan pendidikan inklusif di Sekolah $\mathrm{X}$ ini berjalan dengan baik, diantaranya terlihat adanya sikap penerimaan dari semua masyarakat sekolah, penerimaanpenerimaan peserta didik berkebutuhan khusus di sekolah tersebut pun sangat terbuka, di adakannya sarana dan prasarana yang mendukung peserta didik berkebutuhan khusus untuk menggunakannya, dan penyesuaian kurikulum untuk peserta didik berkebutuhan khusus.

Adapun proses menuju sekolah penyelenggara pendidikan inklusif initidaklahmudah. Dalam pelaksanaannya dibutuhkan perjuangan dan tingkat kesabaran yang cukup tinggi, karena tidak serta merta guru, komite dan siswa maupun orang tua menerima keputusan tersebut. Terlebih Sekolah Dasar X Kota Jambi sejak tahun 2004 telah melakukan tiga kali pergantian kepala sekolah, sehingga 
tidaklah mudah dalam proses pengembangan penyelenggaraan pendidikan inklusif tersebut.

Beberapa faktor mempengaruhi dalam pengambilan kebijakan-kebijakan terkait pelaksanaan pendidikan inklusif ini, ada yang mendukung dan adapula yang menolak kebijakan tersebut. Kepala sekolah sebagai pemimpin harus mampu memberikan penjelasan yang jelas terkait kebijakankebijakan penyelenggaraan pendidikan inklusif di sekolahnya. Hal inilah yang mendasari peneliti tertarik atas fenomena tersebut, dan ingin mengkaji kebijakankebijakan dalam penyelenggaraan pendidikan inklusif, karena tidak banyak kepala sekolah yang berkeinginan untuk menyelenggarakan pendidikan inklusif di sekolah nya.

Berdasarkan latar belakang pemikiran tersebut, maka diuraikan pertanyaan penelitian sebagai berikut: 1) Bagaimana peran kepala sekolah dalam pengambilan kebijakan penyelenggaraan pendidikan inklusif di Sekolah X Kota Jambi?; 2) Apa yang menjadi pendukung dan penghambat kepala sekolah dalam pengambilan kebijakan penyelenggaraan pendidikan inklusif di Sekolah X Kota Jambi?; dan 3) Bagaimana desain kebijakan kepala sekolah dalam penyelenggaraan pendidikan inklusif di Sekolah X Kota Jambi?.

Dengan mengacu pada pertanyaan penelitian tersebut, maka tujuan penelitian ini dimaksud untuk mengetahui: 1) Peran kepala sekolah dalam pengembilan kebijakan penyelenggaraan pendidikan inklusif di Sekolah X Kota Jambi?. 2) Pendukung dan penghambat kepala sekolah dalam pengambilan kebijakan penyelenggaraan pendidikan inklusif di Sekolah $\mathrm{X}$ Kota Jambi. 3) Desain kebijakan kepala sekolah dalam penyelenggaraan pendidikan inklusif di Sekolah X Kota Jambi.

Kajian pustaka dalam penelitian ini adalah:

\section{Hakekat Kebijakan}

Secara etimologi (asal kata) Kebijakan (policy) diturunkan dari bahasa Yunani, yaitu "Polis" yang artinya kota (city). Dapat ditambahkan, kebijakan mengacu kepada cara-cara dari semua bagian pemerintahan mengarahkan untuk mengelola kegiatan mereka. Dalam hal ini, kebijakan berkenaan dengan gagasan pengaturan organisasi dan merupakan pola formal yang sama-sama diterima pemerintah/lembaga sehingga dengan hal itu mereka berusaha mengejar tujuannya (Monahan dan Hengst dalam Syafaruddin; 2008). Menurut Nichols (Syafaruddin: 2008), "kebijakan adalah suatu keputusan yang dipikirkan secara matang dan hati-hati oleh pengambilan keputusan puncak dan bukan kegiatan-kegiatan berulang dan rutin yang terprogram atau terkait dengan aturan-aturan keputusan". Pendapat di atas menunjukkan bahwa kebijakan berarti seperangkat tujuan-tujuan, prinsip-prinsip serta peraturan-peraturan yang membimbing suatu organisasi (Syafaruddin; 2008).

Ada tiga proses kebijakan, yaitu: formulasi, implementasi, dan evaluasi (Putt dan Springer dalam Syafaruddin; 2008). Adapun ketiga proses kebijakan tersebut akan diuraikan sebagai berikut: A. Formulasi Kebijakan. Formulasi kebijakan mengandung beberapa isi penting yang dijadikan sebagai pedoman tindakan sesuai yang direncanakan. Adapun isi kebijakan mencakup: 1) Kepentingan yang terpengaruh oleh kebijakan, 2) Jenis manfaat yang akan dihasilkan, 3) Derajat perubahan yang diinginkan, 4) Kedudukan pembuat kebijakan, 5) (siapa) pelaksana program, 6) Sumber daya yang dikerahkan. B. Implementasi Kebijakan. Implementasi kebijakan pada prinsipnya adalah cara yang dilaksanakan agar sebuah kebijakan dapat mencapai tujuannya (Dwijowijoto, 2003). Dijelasakan oleh Putt dan Springer (Syafaruddin: 2008) implementasi kebijakan adalah serangkaian aktivitas dan keputusan yang memudahkan pernyataan kebijakan dalam formulasi 
terwujud ke dalam praktik organisasi. Untuk mengimplementasikan kebijakan ada dua pilihan langkah yang memungkinkan, yaitu: langsung mengimplementasikan dalam bentuk program-program, atau dapat melalui kebijakan derivet (turunan) dari kebijakan public tersebut. Sejalan dengan pernyataan bahwa (Putt dan Springer dalam Syafaruddin: 2008) implementasi kebijakan memerlukan banyak keputusan dan tindakan seperti; menjamin dan menguatkan berbagai arahan, dan peraturan, mengeluarkan dan membuat penemuan, rekruitmen dan pembinaan personal, menghargai dan membuat kontrak, menciptakan unit organisasi baru supervise staf, membuat anggaran yang diperlukan dan menciptakan bentuk analisis laporan. Implementasi kebijakan bermakna pengembangan kriteria khusus dalam praktik bagi pembuatan keputusan yang mencapai maksud kebijakan. Dalam implementasi kebijakan yang perlu diperhatikan adalah bagaiamana prakondisi untuk keberhasilan pelaksanaan kebijakan, yaitu: komunikasi, sumber daya, disposisi atau sikap dan struktur birokrasi. C. Evaluasi Kebijakan. Suatu kebijakan tidak boleh dibiarkan begitu saja setelah dilaksanakan. Begitu pelakasanaan kebijakan berlangsung selanjutnya perlu diperiksa. Disisi lain, evaluasi dipergunakan untuk mengetahui kesenjangan antara harapan/tujuan dengan kenyataan yang dicapai (Dwijowijoto: 2008). Dengan demikian evaluasi tidak dimaksud mencapai kesalahan para pelaksana kebijakan, akan tetapi pesan utamanya adalah supaya kekurangan dan kelemahan dalam pelakasanaan kebijakan dapat diperbaiki sehingga pencapaian tujuan lebih maksimal (Syafaruddin; 2008).

Untuk mencapai peningkatan mutu sekolah. Kepala sekolah sebagai petugas professional dituntut untuk memformulasikan, mengimplementasikan dan mengevaluasi kebijakan pendidikan. Kebijakan sekolah termasuk dalam spektrum kebijakan pemerintah dalam bidang pendidikan. Duke dan Canady (Syafaruddin: 2008) menjelaskan kebijakan sekolah adalah kerja sama dan keputusan oleh individu atau keinginan kelompok dengan kewenangan yang sah dari dewan sekola, pengawas, administrator sekolah atau komite sekolah dan tanggung jawab bagi kontrak negosiasi. Biasanya kebijakan sekolah dituliskan dan dibagi kepada personel sekolah untuk memperjuangkannya melalui berbagai kegiatan sekolah.

MenurutThompson(Syafaruddin:2008) suatu kebijakan sekolah dibuat oleh orang yang terpilih bertanggung jawab untuk membuat kebijakan pendidikan, dewan sekolah dan unsur lain yang diberi kewenangan membuat kebijakan, baik kepala sekolah maupun pengawas, atau administrator yang memiliki kewenangan mengelola kebijakan dari dewan sekolah.

\section{Kepala Sekolah}

Kepala sekolah bersal dari dua kata yaitu "Kepala" dan "Sekolah" kata kepala dapat diartikan ketua atau pemimpin dalam suatu organisasi atau sebuah lembaga. Sedang sekolah adalah sebuah lembaga di mana menjadi tempat menerima dan memberi pelejaran. Jadi secara umum kepala sekolah dapat diartikan pemimpin sekolah atau suatu lembaga di mana tempat menerima dan memberi pelajaran. Wahjosumidjo (2002) mengartikan bahwa: "Kepala sekolah adalah seorang tenaga fungsional guru yang diberi tugas untuk memimpin suatu sekolah di mana diselenggarakan proses belajar mengajar, atau tempat di mana terjadi interaksi antara guru yang memberi pelajaran dan murid yang menerima pelajaran.

Kepemimpinan merupakan faktor kunci dalam menciptakan perubahan di sekolah. Salah satu fokus kepala sekolah adalah membuat kebijakan. Hasil penelitian Rutter (Syaruddin: 2008), menunjukkan satu faktor penting yang menentukan efektivitas 
sekolah adalah dicapai dengan kebijakan pengembangan sekolah, antara lain: a. Sistem reward dan hukuman. Menambah penggunaan reward menimbulkan kebanggaan dan penghargaan, bekerja sama dengan hasil yang menyenangkan. Sedangkan, masalah pemberlakuan hukuman adalah lebih baik mengurangi hukuman, terutama hukuman fisik supaya sekolah menjadi kondusif. b. Lingkungan sekolah. Kondisi kerja sekolah yang baik, tanggung jawab kepada kebutuhann murid dengan kepedulian yang baik dan dekorasi bangunan serasi, semuanya bekerja sama dengan hasil yang lebih tinggi. c. Sekolah yang berhasil, cendrung membuat penggunaan tugas rumah yang baik, menyusun tujuan akademik yang jelas, memiliki atmosfir percaya diri sebagai suatu kemampuan murid. d. Hasil lebih baik bila guru-guru memberikan contoh perilaku yang baik dalam arti memelihara waktu dengan baik, dan memiliki keinginan menangani masalah murid.

\section{Hakekat Pendidikan Inklusif}

Pendidikan inklusif merupakan ideologi atau cita-cita yang ingin kita raih. Paradigma baru pendidikan inklusif merujuk pada kebutuhan belajar bagi semua peserta didik dengan suatu fokus spesifik pada mereka yang rentan terhadap marjinalisasi atau pemisahan. Dengan demikian pendidikan inklusif adalah pendidikan bagi semua anak tidak terkecuali anak yang mengalami hambatan untuk belajar bersama-sama di kelas dengan pembelajaran yang disesuaikan dengan kebutuhan anak.

$\begin{array}{lll}\text { Pendidikan inklusif } & \text { merupakan } \\ \text { perkembangan } & \text { baru dari } & \text { pendidikan }\end{array}$ terpadu/integrasi. Pada pendidikan inklusif, setiap anak disesuaikan dengan kebutuhan khususnya, semua diusahakan dapat dilayani secara optimal dengan melakukan berbagai modifikasi dan/atau penyesuaian, mulai dari kurikulum, sarana prasarana, tenaga pendidik dan kependidikan, sistem pembelajaran sampai pada sistem penilaiannya. Menurut Juang Sunanto bahwa sekolah penyelenggara inklusif yang ideal adalah: ditandai dengan kurikulum yang fleksibel, sistem evaluasi yang dasarkan pada kemampuan individu, setiap anak disediakan program sesuai dengan kebutuhannya, dan mengutamakan kooperatif dari pada kompetitif. Berdasarkan indikator tersebut, kualitas pelaksanaan pendidikan inklusif di sebuah sekolah dapat di nilai (Media Dunia Disabilitas, No. 14-Februari 2012: 34).

Dengan kata lain bahwa pendidikan inklusif mensyaratkan pihak sekolah harus menyesuaikan kurikulum yang fleksibel, sistem evaluasi yang didasarkan dengan kemampuan anak, setiap anak disediakan program sesuai dengan kebutuhannya, dan mengutamakan kooperatif dari pada kompetitif, bukan peserta didik yang menyesuaikan dengan sistem persekolahan. Dalam pendidikan inklusif anak berkebutuhan khusus maupun anak biasa dapat saling berinteraksi secara wajar sesuai dengan tuntutan kehidupan sehari-hari di masyarakat, dan kebutuhan pendidikannya dapat terpenuhi sesuai potensinya masingmasing. Konsekuensi penyelenggaraan pendidikan inklusif adalah pihak sekolah dituntut melakukaan berbagai perubahan, mulai cara pandang, sikap, sampai pada proses pendidikan yang berorientasi pada kebutuhan individual tanpa diskriminasi.

Menurut Permendiknas nomor 70 tahun 2009 pasal 1 pendidikan inklusif adalah: sistem penyelenggaraan pendidikan yang memberikan kesempatan kepada semua peserta didik yang memiliki kelainan dan memiliki potensi kecerdasan dan/atau bakat istimewa untuk mengikuti pendidikan atau pembelajaran dalam lingkungan pendidikan secara bersama-sama dengan peserta didik pada umumnya.

Stainback dan Stainback (1990) mengemukakan bahwa: sekolah inklusi adalah sekolah yang menampung semua siswa di kelas yang sama. Sekolah ini menyediakan 
program pendidikan yang layak, menantang, tetapi sesuai dengan kemampuan dan kebutuhan setiap siswa, maupun bantuan dan dukungan yang dapat diberikan oleh para guru agar anak-anak berhasil. Lebih dari itu, sekolah inklusi juga merupakan tempat setiap anak dapat diterima, menjadi bagian dari kelas tersebut, dan saling membantu dengan guru dan teman sebayanya, maupun anggota masyarakat lain agar kebutuhan individualnya dapat terpenuhi.

\section{METODE PENELITIAN}

Metode penelitian yang digunakan dalam penelitian ini adalah deskriptif dengan pendekatan kualitatif. Pendekatan kualitatif merupakan metode penelitian yang digunakan untuk meneliti pada kondisi objek alamiah.

Subjek dalam penelitian ini adalah Kepala Sekolah sebagai subjek utamanya dan subjek pendukungnya adalah guru, pengawas Provinsi, pengawas Kota, Koordinator pendidikan Inklusif Provinsi, orang tua, pendamping siswa, dan siswa yang berada di sekolah penyelenggara pendidikan Inklusif di Kota Jambi. Lokasi dalam penelitian ini adalah Sekolah menyelenggarakan pendidikan Inklusif. Adapun Sekolah yang di pakai dalam penelitian ini adalah Sekolah X Kota Jambi. Sekolah Dasar ini ditunjuk langsung oleh pemerintah Provinsi sebagai sekolah yang pertama dalam menyelenggarakan pendidikan Inklusif pada tahun 2004. Adapun penetapan pemilihan lokasi tersebut atas dasar pertimbangan sebagai berikut: (1) Sekolah X Kota Jambi merupakan sekolah pertama kali yang ditunjuk sebagai sekolah penyelenggara pendidikan Inklusif; (2) Jumlah siswa berkebutuhan khusus di Sekolah X Kota Jambi adalah yang terbanyak; (3) Sekolah X Kota Jambi merupakan sekolah yang setiap tahunnya menerima siswa berkebutuhan khusus; dan (4) Merupakan rujukan dari pengawas sekolah dan koordinator pendidikan inklusif.
Sesuai dengan data yang diambil oleh peneliti mengenai Kebijakan-kebijakan Kepala Sekolah dalam Penyelenggaraan Pendidikan Inklusif di Sekolah X Kota Jambi, maka peneliti akan terjun langsung kelapangan untuk mendapatkan data yang dibutuhkan, dengan menggunakan alat pengumpulan data berupa pedoman observasi, wawacara dan studi dokumentasi dengan menggunakan teknik pengumpulan data.

Adapun teknik analisis data yang digunakan dalam penelitian ini adalah analisis data yang dikemukakan oleh Nasution (2003). Adapun analisis data yang maksud adalah: (1) Reduksi Data (Penyajian Data). Reduksi data berarti mengambil bagian pokok atau intisari dari data yang telah diperoleh; (2) Display Data (Pengelompokan Data). Data yang diperoleh kemudian dikelompokkan berdasarkan sistematis rumusan masalah kemudian disajikan dalam deskriptif sehingga data mudah dibaca dan dipahami serta mampu menggambarkan keseluruhan atau bagian-bagian tertentu dari penelitian; dan (3) Vervikasi Data (Penarikan Keseimpulan). Penarikan kesimpulan dilakukan sejak awal hingga akhir proses penelitian guna mempermudah peneliti untuk mendapatkan makna dari setiap data yang dikumpulkan. Kesimpulan yang diambil senantiasa diverivikasi selama penelitian berlangsung untuk menjaga tingkat kepercayaan peneliti.

\section{HASIL PENELITIAN DAN PEMBAHASAN}

\section{Peran Kepala Sekolah dalam Pengambilan Kebijakan Penyelenggaraan Pendidikan Inklusif di Sekolah X Kota Jambi}

Kepala sekolah memiliki kebijakan dalam penerima siswa baru, kepala sekolah berhak menolak dan menerima siswa-siswa baru, terlebih jika anak berkebutuhan khusus yang mendaftar terlalu banyak. Tetapi kebijakan dari kepala sekolah adalah, kepala sekolah meminta koordinator pendidikan inklusif untuk membantu dalam menseleksi siswa- 
siswa baru yang mengalami hambatan dalam belajar dan dibantu oleh guru-guru SLB untuk mengasesmen anak. Terkait guru pembimbing khusus (GPK) yang belum ada, maka kepala sekolah memberikan kebijakan untuk memperbolehkan orang tua siswa mendampingin anaknya di dalam kelas. Hal ini dilakukan untuk mempermudah tugas guru di dalam kelas ketika mengajar.

Adapun peran kepala sekolah terkait pengambilan kebijakan tentang kurikulum bagi peserta didik berkebutuhan khusus adalah, kepala sekolah memberikan kebijakan untuk menjadikan kurikulum tersebut sefleksibel mungkin dan disesuaikan dengan kemampuan peserta didik berkebutuhan khusus. Selanjutnya untuk proses pembuatan program pembelajaran dan evaluasi dilakukan bersama-sama orang tua siswa tersebut. Kebijakan kepala sekolah terkait seting pembelajaran dalam pendidikan inklusif yaitu kepala sekolah memberikan kebijakan kepada semua guru untuk bebas mengatur kondisi ruang kelasnya. Dibuat senyaman dan seaman mungkin sehingga peserta didik merasa senang. Adapun untuk pendekatan dalam pembelajaran kepala sekolah meminta guru-guru untuk selalu memvariasikan metode mengajarnya, agar anak tidak bosan dan jenuh.

Selanjutnya untuk pendanaan penyelenggaraan pendidikan inklusif, kepala sekolah membuat kebijakan seperti mengajukan dana bantuan ke pihak-pihak yang terkait dengan penyelenggaraan pendidikan inklusif, seperti ke pusat. Hal ini dilakukan kepala sekolah karena pendanaan penyelenggaraan pendidikan inklusif di Sekolah X Kota Jambi bersifat mandiri, kepala sekolah bersama guru-guru bekerja sama untuk mencari dana bantuan tersebut. Dari dana yang didapatkan tersebut, kepala sekolah memberikan kebijakan untuk menggunakan dana tersebut membangun sarana dan prasarana serta perbaikan infrastruktur sekolah. Hal ini dilakukan untuk mengakomodasi kebutuhan peserta didik. Adanya sarana dan prasarana yang memadai sangat mendukung terciptanya suasana yang inklusif. Sarana dan prasarana yang mudah dijangkau oleh peserta didik berkebutuhan khusus dan mudah untuk diakses menjadikan sekolah lebih inklusif.

\section{Pendukung dan penghambat kepala sekolah dalam pengambilan kebijakan penyelenggaraan pendidikan inklusif di Sekolah X Kota Jambi}

Adanya dukungan dari semua masyarakat sekolah terkait pengambilan kebijakan penyelenggaraan pendidikan inklusif mendorong kepala sekolah untuk lebih memperhatikan penyelenggaraan pendidikan inklusif di sekolahnya. Berdasarkan hasil penelitian dilapangan di temukan beberapa faktor pendukung penyelenggaraan pendidikan inklusif di Sekolah X Kota Jambi, antara lain; (1) Kepala sekolah beserta tenaga pendidik dan kependidikan memiliki sikap penerimaan yang besar terhadap perbedaan-perbedaan. Sikap penerimaan terhadap perbedaan inilah yang menjadikan penyelenggaraan pendidikan inklusif di Sekolah X kota Jambi berjalan. Dari kepala sekolah, guru, orang tua, dan anak sangat menerima segala perbedaan yang ada pada setiap peserta didik. Tidak ada sikap diskriminatif yang mereka perlihatkan kepada para peserta didik berkebutuhan khusus, semua masyarakat sekolah memiliki sikap yang terbuka dan menerima semua perbedaan tersebut. Hal ini sesuai dengan yang disampaikan oleh Tarsidi et al (2008) bahwa sekolah inklusif memiliki karakteristik: Tidak diskrimintaif. Artinya sekolah inklusif harus memberikan layanan pendidikan kepada setiap anak tanpa terkecuali dan pengakuan dan penghargaan terhadap keragaman individu anak. Berdasarkan temuan penelitian di lapangan, dapat disimpulkan bahwa Kepala sekolah beserta guru-guru di Sekolah X Kota Jambi memiliki sikap terbuka dan sikap penerimaan yang besar 
terhadap perbedaan-perbedaan yang ada pada peserta didik berkebutuhan khusus; (2) Adanya donator-donatur yang memberikan bantuan beasiswa kepada peserta didik berkebutuhan khusus. Berdasarkan temuan peneliti di lapangan, didapatkan bahwa kepala sekolah berhasil mencari dana bantuan untuk mengembangkan penyelenggraan sekolah inklusif di Sekolah X Kota Jambi. Adanya donator-donatur yang memberikan bantuan seperti beasiswa pendidikan bagi peserta didik berkebutuhan khusus setiap semesternya membuktikan bahwa kebijakan yang di buat kepala sekolah di dukung oleh semua pihak, sehingga beberapa donator bersedia membantu untuk suksesnya penyelenggaraan pendidikan inklusif di Sekolah X Kota Jambi; (3) Kurikulum sekolah yang fleksibel. Berdasarkan temuan peneliti di lapangan, di simpulkan bahwa, kurikulum yang digunakan di Sekolah X Kota Jambi di buat sefleksibel mungkin, dan disesuaikan dengan kemampuan peserta didik berkebutuhan khusus. Hal ini sesuai dengan Peraturan Menteri Pendidikan Nasional Nomor 70 tahun 2009 tentang pendidikan inklusif bagi peserta didik yang memiliki kelainan dan memiliki potensi kecerdasan dan/atau bakat istimewa, dijelaskan bahwa Satuan pendidikan penyelenggara pendidikan inklusif menggunakan kurikulum tingkat satuan pendidikan yang mengakomodasi kebutuhan dan kemampuan peserta didik sesuai dengan bakat, minat dan potensinya. Dijelaskan bahwa dalam pembelajaran perlu mempertimbangkan prinsip-prinsip pembelajaran yang disesuaikan dengan karakteristik belajar peserta didik. Begitu juga dengan system penilaian, yang mana mengacu pada kurikulum yang diterapkan. Hal ini didasari oleh kepala sekolah bahwa setiap anak itu memiliki perbedaan dan kemampuan menguasai pelajaran yang tidak pernah sama. Sehingga kepala sekolah membuat kebijakan untuk menyesuaikan kurikulum dengan kamampuan peserta didik nya, sehingga kurikulum yang diberlakukan bersifat fleksibel yang dapat memberikan kesempatan bagi peserta didik berkebutuhan khusus dapat belajar bersama-sama dengan peserta didik lainnya; (4) Adanya sarana dan prasarana serta sumber belajar yang mendukung. Berdasarkan temuan peneliti di lapangan, dapat disimpulkan bahwa sarana dan prasarana serta sumber belajar di Sekolah $\mathrm{X}$ Kota Jambi cukup memadai dan dapat di gunakan/akses oleh semua. Kebijakan kepala sekolah dalam pengadaan sarana dan prasarana serta sumber belajar, sangat didukung oleh semua pihak. Hal ini karena sarana dan prasarana tersebut sangat penting bagi sekolah penyelenggara pendidikan inklusif, agar peserta didik berkebutuhan khusus dapat terbantu dan sama-sama mendapatkan kesempatan dalam segala aspek kehidupan bermasyarakat. Hal ini sesuai dengan yang disampaikan oleh Tarsidi, et al (2008) pada poin 3 yang mengatakan bahwa sekolah inklusif memiliki karakteristik: Fasilitas belajar dan lingkungan memberi kemudahan dan rasa aman kepada setiap anak; sarana fisik sekolah memudahkan, aman dan nyaman untuk digunakan oleh setiap anak termasuk anak berkebutuhan khusus. Menurut Pasal 1 ayat 4 Undang-Undang Nomor 4 tahun 1997 tentang penyandang cacat, aksesibiltas adalah kemudahan yang disediakan bagi penyandang cacat guna mewujudkan kesempatan dalam segala aspek kehidupan, diperjelas dengan pasal 10 ayat 2. Penyediaan aksesibilitas dimaksud untuk menciptakan keadaan dan lingkungan yang lebih menunjang penyandang cacat dapat sepenuhnya hidup bermasyarakat. Sejalan dengan itu, yang dimaksud dengan aksesibilitas fisik adalah lingkungan fisik yang oleh penyandang cacat dapat di hampiri, dimasuki, atau dilewati, dan penyandang cacat dapat menggunakan wilayah dan fasilitas yang terdapat didalamnya tanpa bantuan. Dalam pengertian yang lebih luas, aksesibilitas fisik mencakup akses terhadap berbagai bangunan, alat transportasi dan komunikasi, serta berbagai fasilitas diluar 
ruangan termasuk sarana rekreasi. Adanya sarana dan prasarana serta sumber belajar di Sekolah X Kota Jambi sangat membantu semua pihak, baik itu kepala sekolah, guru, orang tua, dan peserta didik. Dukungan untuk pengadaan sarana dan prasarana serta sumber belajar ini nyata di perlihatkan oleh semua pihak, sehingga Sekolah X Kota Jambi memiliki sarana dan prasarana serta sumber belajar yang sangat mendukung,dan mudah diakses oleh semua; dan (5) Dekat dengan Sekolah Luar Biasa. Berdasarkan temuan peneliti dilapangan, untuk letak Sekolah X Kota Jambi sangat strategis. Sekolah X Kota Jambi berdekatan dengan Sekolah Luar Biasa, sehingga hal ini dapat memudahkan pihak Sekolah X untuk berdiskusi atau meminta bantuan kepada Sekolah Luar Biasa. Salah satu kebijakan dari kepala sekolah adalah menjalin kerjasama dengan Sekolah Luar Biasa, dan kerjasama tersebut sangat didukung oleh seluruh masyarakat Sekolah X Kota Jambi.

Selain faktor pendukung terkait kebijakan kepala sekolah dalam penyelenggaraan pendidikan inklusif, terdapat pula faktor penghambat kepala sekolah dalam penyelenggaran pendidikan inklusif. Adapun beberapa faktor penghambat terkait kebijakan kepala sekolah dalam penyelenggaraan pendidikan inklusif di Sekolah X Kota Jambi; (1) Tidak adanya guru pembimbing khusus. Berdasarkan temuan peneliti di lapangan, dapat disimpulkan bahwa Sekolah X Kota Jambi belum memiliki guru pembimbing khusus. Kebijakan kepala sekolah terkait penerimaan guru pembimbing khusus belum terlaksana, sehingga terkadang banyak hambatan-hambatan pada peserta didik berkebutuhan khusus yang tidak di ketahui oleh kepala sekolah, dan guru di kelas. Di sekolah penyelenggara pendidikan inklusif perlu disediakan guru pembimbing khusus (GPK) seperti dijelaskan Peraturan Menteri Pendidikan Nasional Nomor 70 Tahun 2009 tentang Pendidikan Inklusif bagi peserta didik yang memiliki kelainan dan memiliki potensi kecerdasan dan/atau bakat istimewa menyebutkan bahwa Pemerintah kabupaten/ kota perlu menyediakan paling sedikit 1 (satu) orang guru pembimbing khusus (GPK) pada satuan pendidikan yang ditunjuk untuk menyelenggarakan pendidikan inklusif. Tidak adanya guru pembimbing khusus merupakan salah satu faktor penghambat dalam pelaksanaan penyelenggaraan pendidikan inklusif, sehingga sangat di perlukan kebijakan yang mengatur terkait adanya guru pembimbing khusus di sekolah penyelenggara pendidikan inklusif. Karena itu kepala sekolah sangat mengharapkan adanya satu guru pembimbing khusus di Sekolah X Kota Jambi agar penyelenggara pendidikan inklusif di Sekolah X Kota Jambi dapat berjalan dengan baik; (2) Sikap Penerimaan orang tua. Sikap penerimaan terhadap perbedaan-perbedaan sangat penting bagi keterlaksananya penyelenggaraan pendidikan inklusif. Jika belum memiliki sikap menerima terhadap perbedaan akan banyak kendala dan hambatan yang terjadi ketika akan menyelenggarakan pendidikan inklusif di suatu sekolah. Seperti halnya di Sekolah X Kota Jambi ini, terdapat beberapa dari orang tua siswa yang sedikit masih belum bisa menerima perbedaan tersebut. Para orang tua tersebut masih belum bisa menerima bahwa anaknya di satukan dengan peserta didik berkebutuhan khusus. Hal inilah yang menjadi salah satu faktor penghambat dalam menyukseskan penyelenggaraan pendidikan inklusif di Sekolah X Kota Jambi. Kepala sekolah sudah berupaya dalam memberikan pemahaman terhadap beberapa orang tua tentang pendidikan inklusif, dan pentingnya menghargai perbedaan setiap individu pada peserta didik; (3) Minim dukungan dari Dinas Pendidikan Kota dan Provinsi. Berdasarkan temuan peneliti dan wawancara terhadap kepala sekolah terkait dukungan dari pemerintah di simpulkan bahwa, minim sekali perhatian dari Dinas Pendidikan Kota dan Provinsi terhadap penyelenggaraan 


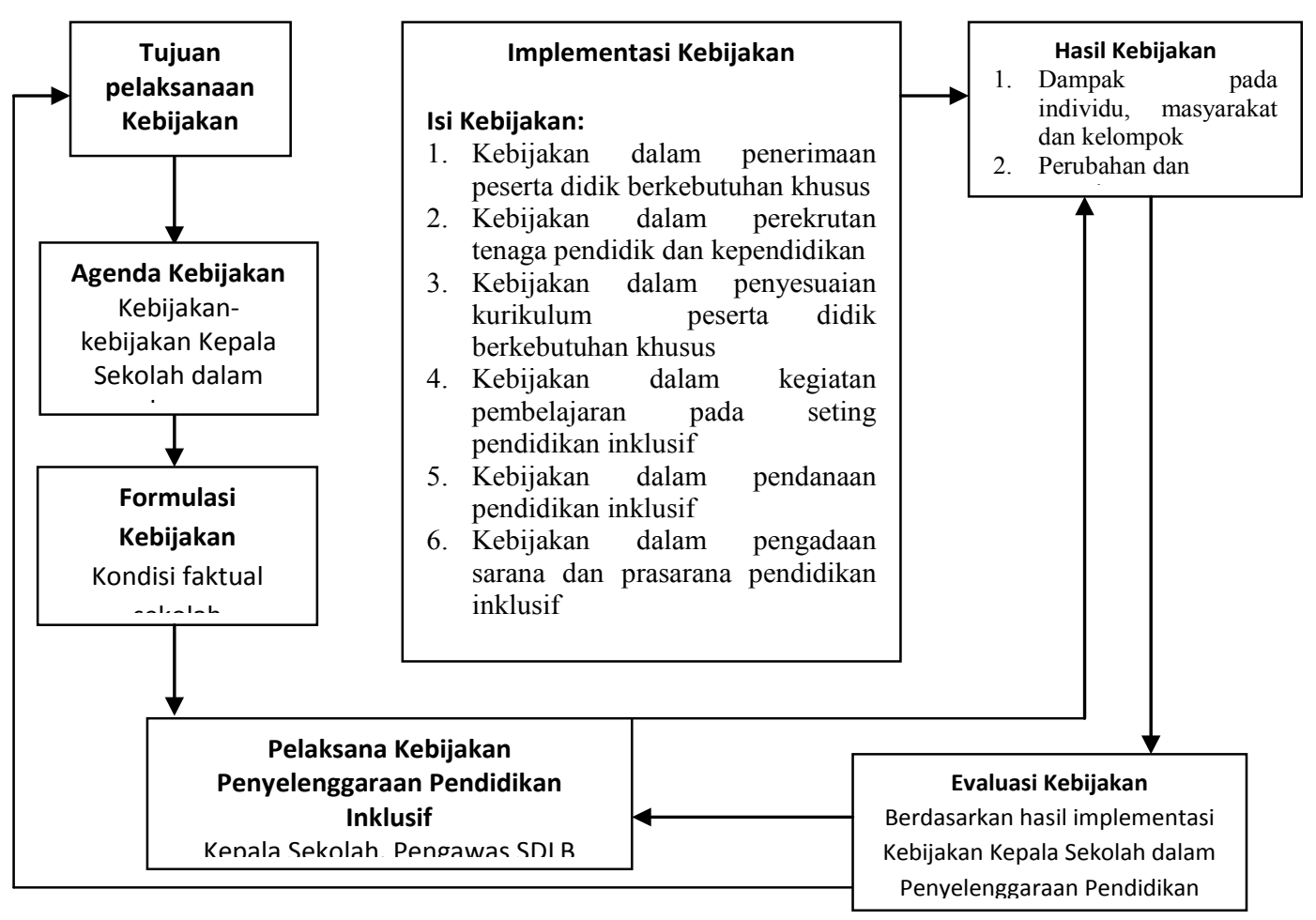

pendidikan inklusif di Sekolah X Kota Jambi. Hal ini merupakan faktor penghambat dalam mengembangkan pendidikan inklusif di Sekolah X Kota Jambi. Hal ini tidak sesuai dengan Permendiknas Nomor 70 Tahun 2009 pasal 6 yang menyatakan bahwa: Pemerintah kabupaten/kota menjamin terselengaranya pendidikan inklusif sesuai dengan kebutuhan peserta didik. Pemerintah kabupaten/ kota menjamin tersedianya sumberdaya pendidikan inklusif pada satuan pendidikan yang ditunjuk. Pemerintah dan pemerintah provinsi membantu tersedianya sumber daya pendidikan inklusif. Beberapa permohonan bantuan dari sekolah untuk Dinas Pendidikan Provinsi dan Kota belum di tanggapi, seperti bantuan dalam pengadaan sarana dan prasarana serta bantuan terkait permohonan mendatangkan guru pembimbing khusus ke Sekolah X Kota Jambi yang sampai saat sekarang ini belum di tanggapi.

Partisipasi dari semua komponen sekolah terhadap kebijakan penyelenggaraan pendidikan inklusif. Berdasarkan temuan peneliti di lapangan dapat di simpulkan terkait partisipasi semua masyarakat sekolah terkait kebijakan penyelenggaraan pendidikan inklusif di Sekolah X Kota Jambi bahwa semua masyarakat sekolah berpartisipasi untuk mendukung kebijakan tersebut. Dukungan atas kebijakan tersebut ditunjukkan oleh seluruh masyarakat sekolah dengan berpartisipasi di dalamnya. ketika kepala sekolah membuat kebijakan terkait pendidikan inklusif, maka semua masyarakat sekolah berpartispasi dalam menyukseskan kebijakan tersebut. Terutama para tenaga pendidik/guru sangat bersemangat ketika diberikan kesempatan untuk mengikuti pelatihan, seminar dan workshop terkait pendidikan inklusif.

\section{Desain kebijakan Kepala Sekolah dalam Penyelenggaraan Pendidikan Inklusif di Sekolah X Kota Jambi}

Pada dasarnya desain kebijakan kepala sekolah dalam penyelenggaraan pendidikan inklusif tersebut adalah desain yang di susun sedemikian rupa berdasarkan hasil kajian peneliti di lapangan. Di mana desain kebijakan tersebut mengacu pada tiga aspek yaitu formulasi kebijakan, implementasi kebijakan dan evaluasi kebijakan. Sehingga nantinya tersusun sebuah desain kebijakan kepala sekolah dalam penyelenggaraan 
pendidikan inklusif yang di sesuaikan dengan kondisi di lapangan.

Desain ini disusun berdasarkan agenda kebijakan yaitu kebijakan-kebijakan kepala sekolah dalam penyelenggaraan pendidikan inklusif. Desain kebijakan ini mangacu pada tiga aspek yaitu formulasi kebijakan, implementasi kebijakan dan evaluasi kebijakan. Selanjutnya tiga aspek tersebut di visualisasikan dalam bentuk bagan di bawah ini.

a. Tujuan pelaksanaan kebijakan

Pada bagan diatas terdapat tujuan pelaksanaan kebijakan. Tujuan pelaksanaan kebijakan ini merupakan tujuan yang hendak dicapai oleh kepala sekolah dalam proses pembuatan kebijakan. Tujuan pelaksanaan kebijakan ini dilakukan untuk mengembangkan penyelenggaraan pendidikan inklusif di Sekolah X Kota Jambi menjadi lebih optimal.

b. Agenda kebijakan

Adanya kebijakan yang dibuat tidak terlepas dari agenda kebijakan yang mendasari pembuatan kebijakan tersebut. Dimana yang menjadi agenda kebijakan pendidikan inklusif ini adalah kebijakankebijakan kepala sekolah dalam penyelenggaraan pendidikan inklusif. Agenda kebijakan inilah yang selanjutnya akan ditindak lanjuti dalam bentuk formulasi kebijakan.

\section{c. Formulasi kebijakan}

Menurut Riant Nugroho (2009), proses dasar kebijakan yang dikembangkan oleh para ilmuwan kebijakan publik mempunyai kesamaan, yaitu, proses kebijakan berjalan dari formulasi menju implementasi, untuk mencapai kinerja/ evaluasi kebijakan. Selanjutnya pada bagan terdapat proses formulasi kebijakan yang merupakan turunan dari agenda kebijakan yang telah di rencanakan.
Adapaun dalam formulasi kebijakan pada penelitian ini lebih ke arah kondisi faktual kebijakan kepala sekolah dalam penyelenggaraan pendidikan inklusif. Kondisi faktual ini merupakan kondisi nyata dilapangan yang peneliti amati. Tidak ada intervensi yang peneliti lakukan ketika mengamati kondisi kebijakankebijakan kepala sekolah tersebut.

\section{d. Lingkungan kebijakan}

Dan semua hal yang diamati tersebut tidak terlepas dari lingkungan kebijakan yang mendukung adanya kebijakan tersebut. Adapun lingkungan kebijakan tersebut adalah kepala sekolah sebagai pengambil kebijakan, pengawas SDLB Kota, pengawas SD Provinsi, guru, orang tua dan peserta didik. Lingkungan kebijakan ini berkaitan dengan masukan-masukan yang diberikan kepada kepala sekolah untuk membuat kebijakan-kebijakan yang berkaitan dengan penyelenggaraan pendidikan inklusif.

e. Implementasi kebijakan

Setelah adanya proses formulasi kebijakan, selanjutnya adalah proses implementasi kebijakan. Dimana implementasi kebijakan tersebut terdiri dari isi kebijakan dan konteks implmentasi. Adapun isi dari kebijakan tersebut adalah disesuaikan dengan formulasi kebijakan yang telah dirumuskan yaitu, kebijakan dalam penerimaan peserta didik berkebutuhan khusus, kebijakan dalam perekrutan tenaga pendidik dan kependidikan, kebijakan dalam penyesuaian kurikulum peserta didik berkebutuhan khusus, kebijakan dalam kegiatan pembelajaran pada seting inklusif, kebijakan dalam pendanaan pendidikan inklusif dan kebijakan dalam pengadaan sarana dan prasarana pendidikan inklusif. Adapun mengenai implementasi kebijakan terkait hal-hal yang diamati dalam proses formulasi kebijakan tersebut, telah di 
bahas pada bab pembahasan peran kepala sekolah dalam pengambilan kebijakan penyelenggaran pendidikan inklusif di Sekolah X Kota Jambi. Selanjutnya konten implementasi, dalam implementasi kebijakan ini adalah dukungan terhadap pengambilan kebijakan pendidikan inklusif, hambatan terhadap pengambilan kebijakan pendidikan inklusif, dan partisipasi masyarakat sekolah terhadap pengambilan kebijakan penyelenggaraan pendidikan inklusif.

Adapun dukungan-dukungan yang terkait pengambilan kebijakan pendidikan inklusif ini adalah, kepala sekolah beserta tenaga pendidik dan kependidikan memiliki sikap penerimaan yang besar terhadap perbedaan. Sikap penerimaan terhadap perbedaan inilah yang menjadikan penyelenggaraan pendidikan inklusif di Sekolah X kota Jambi berjalan. Tidak ada sikap diskrimintaif yang ditunjukkan oleh kepala sekolah dan guru-guru. Semua anak memiliki hak yang sama dalam memperoleh pendidikan dan hak untuk belajar bersamasama teman sebayanya. Selanjutnya adalah adanya donatur-donatur yang memberikan bantuan beasiswa kepada peserta didik berkebutuhan khusus. Beberapa elemen masyarakat yang peduli terhadap pendidikan inklusif di Sekolah $X$ Kota Jambi bersama-sama memberikan support dan dukungan terhadap penyelenggaraan pendidikan inklusif ini, yang diantaranya adalah memberikan bantuan beasiswa pendidikan kepada peserta didik berkebutuhan khusus. Hal inilah yang menjadi dukungan bagi kepala sekolah dalam pengambilan kebijakan penyelenggaraan pendidikan inklusif. Selanjutnya adalah kurikulum sekolah yang fleksibel. Berdasarkan Peraturan Menteri Pendidikan Nasional Nomor 70 tahun 2009 tentang pendidikan inklusif bagi peserta didik yang memiliki kelainan dan memiliki potensi kecerdasan dan/atau bakat istimewa, dijelaskan bahwa Satuan pendidikan penyelenggara pendidikan inklusif menggunakan kurikulum tingkat satuan pendidikan yang mengakomodasi kebutuhan dan kemampuan peserta didik sesuai dengan bakat, minat dan potensinya. Dasar hukum inilah yang menjadikan faktor pendukung bagi kepala sekolah dalam membuat kebijakan dalam penyelenggaraan pendidikan inklusif. Selanjutnya adalah adanya sarana dan prasarana serta sumber belajar yang mendukung terciptanya suasana dan sekolah yang inklusif. Sarana dan prasarana yang mudah di akses bagi peserta didik serta mudah di jangkau dan dapat dipergunakan oleh semua masyarakat sekolah inilah yang menjadikan faktor pendukung kepala sekolah dalam pengambilan kebijakan penyelenggaraan pendidikan inklusif. Selanjutnya Sekolah X Kota Jambi berdekatan dengan Sekolah Luar Biasa sehingga dalam proses pengambilan kebijakan penyelenggaraan pendidikan inklusif, kepala sekolah didukung langsung oleh Sekolah Luar Biasa tersebut.

Adapun konteks implementasi selanjutnya adalah faktor penghambat pengambilan kebijakan penyelenggaraan pendidikan inklusif oleh kepala sekolah. Adapun faktor penghambat dalam pengambilan kebijakan tersebut adalah tidak adanya guru pembimbing khusus. Kepala sekolah sangat mengaharapkan adanya guru pembimbing khusus di Sekolah X Kota Jambi.Adanya gurupembimbingkhususini sangat berperan di sekolah penyelenggara pendidikan inklusif. Tidak adanya guru pembimbing khusus ini merupakan faktor penghambat bagi kepala sekolah dalam pengambilan kebijakan penyelenggaraan pendidikan inklusif. Faktor penghambat selanjutnya adalah sikap penerimaan orang tua. Masih ada sebagian dari orang 
tua peserta didik yang tidak mengalami disabilitas tidak mendukung kebijakan kepala sekolah dalam penyelenggaraan pendidikan inklusif di Sekolah $\mathrm{X}$ Kota Jambi. Masih ada rasa takut dan cemas ketika anaknya di satukan dalam kelompok belajar bersama peserta didik berkebutuhan khusus. Faktor penghambat selanjutnya adalah minimya dukungan dari pemerintah provinsi dan kota. Kebijakan-kebijakan yang di buat oleh kepala sekolah terkait penyelenggaraan pendidikan inklusif ini terkadang tidak terlalu di tanggapi oleh pemerintah provinsi dan kota. Berbagai upaya telah dilakukan kepala sekolah untuk meminta perhatian kepada pemerintah provinsi dan kota, tapi sampai saat sekarang ini masih minim perhatian tersebut. Sehingga ini merupakan faktor penghambat kepala sekolah dalam pengambilan kebijakan terkait penyelenggaraan pendidikan inklusif.

Konteks implementasi selanjutnya adalah partisipasi masyarakat sekolah terhadap kebijakan pendidikan inklusif. Partisipasi semua masyarakat sekolah terkait kebijakan penyelenggaraan pendidikan inklusif di Sekolah X Kota Jambi, bahwa semua masyarakat sekolah berpartisipasi untuk mendukung kebijakan tersebut. Dukungan atas kebijakan tersebut ditunjukkan oleh seluruh masyarakat sekolah dengan berpartisipasi di dalamnya. Ketika kepala sekolah membuat kebijakan terkait pendidikan inklusif, maka semua komponen sekolah berpartispasi dalam menyukseskan kebijakan tersebut.

\section{f. Hasil kebijakan}

Setelah kebijakan-kebijakan tersebut di implementasi, diharapkan adanya hasil kebijakan yang berdampak pada individu, masyarakat dan kelompok, serta adanya perubahan dan penerimaan dari masyarakat sekolah terhadap kebijakan- kebijakan penyelenggaraan pendidikan inklusif tersebut. Dari hasil kebijakan inilah selanjutnya masuk ketahapan kebijakan selanjutnya yaitu evaluasi kebijakan.

\section{g. Evaluasi kebijakan}

Evaluasi tersebut berdasarkan proses implementasi kebijakan yang telah di lakukan dan memberikan hasil apakah implmentasi kebijakan tersebut berjalan ataukah tidak?. Evaluasi kebijakan yang telah di jalankan tersebut merupakan tujuan dari pelaksanaan kebijakan. Jika masih terdapat kebijakan-kebijakan yang tidak sesuai maka perlu dirancang kembali kebijakan yang sesuai dengan kondisi dilapangan.

\section{KESIMPULAN}

Dari hasil penelitian dan pembahasan, dapat disimpulkan terkait kebijakan-kebijakan kepala sekolah dalam penyelenggaraan pendidikan inklusif di Sekolah $\mathrm{X}$ Kota Jambi, yang mana dalam pengambilan kebijakan tersebut kepala sekolah melakukan pengumpulan data terlebih dahulu terkait penyelenggraan pendidikan inklusif di Sekolah X Kota Jambi. Setelah terkumpul semua data yang ada, kepala sekolah mengimplementasikan kebijakan tersebut. Dalam melaksanakan implementasi tersebut, beberapa faktor mempengaruhi kebijakan yang dibuat, ada yang mendukung dan adapula yang menolak kebijakan tersebut.

Adapun faktor pendukung kepala sekolah dalam pengambilan kebijakan adalah: 1) Kepala sekolah beserta tenaga pendidik dan kependidikan memiliki sikap penerimaan yang besar terhadap perbedaan-perbedaan. 2) Adanya donator-donatur yang memberikan bantuan beasiswa kepada peserta didik berkebutuhan khusus. 3) Kurikulum sekolah yang fleksibel. 4) Adanya sarana dan prasarana serta sumber belajar yang mendukung. 5) Dekat dengan Sekolah Luar 
Biasa.

Adapun faktor penghambat kepala sekolah dalam pengambilan kebijakan adalah: 1)
Tidak adanya guru pembimbing khusus. 2) Sikap Penerimaan orang tua. 3) Minim dukungan dari Dinas Pendidikan Kota dan Provinsi.

\section{DAFTAR PUSTAKA}

Nasution (1992). Metode Research. Bandung: Jemmars.

Permendiknas. (2009). No 70 tahun 2009. Tentang Pendidikan Inklusif Bagi Peserta Didik yang Memiliki Kelainan dan Memiliki Potensi Kecerdasan dan atau Bakat Khsusus. Jakarta: Departemen Pendidikan Nasional

Syafaruddin. (2008). Efektivitas Kebijakan Pendidikan. Jakarta: PT Rineka Cipta 